\title{
PROSPECTS OF TRADITIONAL AND NON-TRADITIONAL SECURITY CONCERNS IN INDIAN-PAKISTANI RIVALRY
}

\author{
Saleem Raza Baig ${ }^{*}$
}

\begin{abstract}
Security has always been a force multiplier to concentrate over the traditional military stockpile for the perceived threats in the modern days of nation states focused on the conceptualization of non-traditional security dwelling into integration, like European Union's regional cooperation rather than towards diverting assets on further devolutions or disintegrations over the phenomenon of 'security dilemma' as is the case of India and Pakistan. Indeed, the later phenomenological conceptual framework had never diminished in its essence which forced the welfare states as well as the major powers including USA to maintain traditional military hardware in the age of $5^{\text {th }}$ generation of warfare. India and Pakistan remained into zenith of vicious cycle of stock piling of latest weaponry under the outcome of irrational conclusions of prisoner's dilemma of the belligerents fuelling traditional enthusiasm of ethnic and religious vehemence. This research is an effort to find out the gaps in easing the tensions over the détente and interdependent security while moving towards non-traditional security and instead of transforming both the states into welfare states or formerly highlighted integration of the region. Resultantly, the shedding away of the existing survival and deterrence phase led to the devolution of traditional hype of grotesque nuclear flash point.
\end{abstract}

Keywords: Security, $5^{\text {th }}$ generation warfare, Indo-Pak rivalry due to security and prisoner's dilemmas, integration for interdependent comprehensive security, traditional society

\section{Introduction}

Security probably remained a debatable terminology amongst scholars if not ambiguous or confusing as highlighted by Barry Buzan ${ }^{1}$, maintaining a threshold level of survival or deterrent ${ }^{2}$ conceptualization transforming from individual security in pursuit of happiness ${ }^{3}$ or scarce values of degraded quality of life in domestic affairs to state, regional or global security dwelling in freedom/protection from threats or external

\footnotetext{
${ }^{*}$ Saleem Raza Baig, Ph.D. Student, Department of International Relations, University of Karachi

${ }^{1}$ Buzan, Barry, People, Sate and Fear: An Agenda for National Security Studies in Post-Cold war Era. (Colorado: Lynne Reiner Publishers, Inc., 1991), pp.1-7.

${ }^{2}$ Caroline, Kennedy in eds. Collins, Alans, Contemporary Security Studies, (Oxford: Oxford University Press, 1983), pp. 118-120.

${ }^{3}$ Carr, E H, in eds., Christopher W Hughes and Lai, Yew Meng, Security Studies: A Reader, (Oxon: Routledge, 2011), pp. 106-9.
} 
aggressions, worries and danger ${ }^{4}$. However, the security due to its epistemological diversification from psychological effects in domestic affairs to physical build up in global deterrent military hardware of nuclear arsenals have overshadowed the ontological uniqueness to take unending precautionary measures both in individual as well as state security. The simplest security concerns of traditional military warfare to interdependent comprehensive security of environment, societal, economic and political sectors $^{5}$ in wholesome had always been a source of concern world over.

The Indian Sub-continent and surrounding region most of the times has been a flash point since decades which attracted massive attention of tradition security concerns both normatively ideological warfare developments and idiosyncratic or descriptive physical display of $5^{\text {th }}$ generation of warfare ${ }^{6}$ arsenals of the state of art equipment. Indeed, these developments remained confined at the cost of shedding away already meager resources of the budget constraints affecting the inversely proportional quality of the life of the inhabitants of the region diminishing the pursuits of the happiness in disguised survival. On the contrarily, the survival and deterrence proponents of the traditional security never let the thought process drifting towards integrated comprehensive security more relied on economic, political, societal and environmental security. ${ }^{7}$

The objective of this study is to find out the prospects of traditional security in the context of Indian-Pakistani security dilemma ${ }^{8}$ that forced belligerents over irrational outcomes of Prisoner's dilemma ${ }^{9}$ as well as the complex of 'Keynesian Military Economy ${ }^{10}$. However, before considering the complex interaction of both the states it would be imperative to analyze the transition and evolution of traditional military and non-traditional human or domestic security both at national as well as international levels. Henceforth, the diversified scholarly approaches of both the aforementioned security concerns amongst human security verses traditional military security world over, at regional and international levels vis-à-vis the revolution in military affairs RMA, and the wars of identity or Secret Wars ${ }^{11}$ forced the Asian region into unending crisis, are comprehensively discussed in this study.

\footnotetext{
${ }^{4}$ Ibid.

${ }^{5}$ Buzan, Barry, People, Sate and Fear: An Agenda for National Security Studies in Post-Cold war Era. (Colorado: Lynne Reiner Publishers, Inc., 1991), pp. 116-134.

${ }^{6}$ Brain, M Drinkwine, Colonel, The Serpent in our Garden: Al Qaida and the Long War, available on http://www.strategicstudiesinstitute.army.mil/. Accessed on 12 October 2016.,pp. 20-2.

${ }^{7}$ Buzan, Barry, People, Sate and Fear: An Agenda for National Security Studies in Post-Cold war Era. (Colorado: Lynne Reiner Publishers, Inc., 1991), pp. 116-134.

${ }^{8}$ The scholarly terminological concepts of Security and Prisoner's Dilemmas were coined to establish a security relationship which is complex and interdependent over belligerent's military developments. The former concept originates an arms race in pursuit of security threat of the opponent whereas the later develops an irrational outcome of the rational decision(s) of both the opponents.

${ }^{9}$ Russel, F Leng, in eds., T V Paul, The India-Pakistan Conflict: An Enduring Rivalry, (Cambridge: Cambridge University Press, 2005), pp. 104.

${ }^{10}$ Fanny, Coulomb, in eds., Derek, L Braddon and Keith Hartley, Handbook on the Economics of the Conflict, (Glos, UK: Edward Elgar Publishing Limited), pp. 20-1.

${ }^{11}$ The concepts of 'revolutions in military affairs' (RMA) and 'secret war or war of hatred' were introduced after the transformation of $5^{\text {th }}$ generation of warfare in traditional military security that were associated due to the sophisticated technological advancement in war munitions, remotely piloted vehicles (drones), improvised explosive devices (IEDs) and non-state actors in warfare technology.
} 


\section{Methodology}

The research is focused on both primary and secondary sources in detail. However, the main thrust of research remained confined to qualitative theory intertwined in empirical analysis based on logical reasoning. The primary methods of research also included the visits/interviews to various scholars and dignitaries of civil-military leadership displaying a role in security concerns and state affairs especially in Pakistan against India. Moreover, the primary research was also inclined to consult the speeches, statements and autobiographies or write ups compiled by the concerned personalities. Similarly, the secondary source was also extensively used that was available in scholarly work and published from print and mass media.

\section{Literature Review}

Theoretically, the research revolves around the conceptual framework of state security illustrated in the scholarly efforts of Max Weber, Rousseau, Micheal Mann, Barry Buzan, Machiavelli, David P Gauthier, Graham Evans, Jeffrey Newham, Robert Jackson, Dwayne N Hunt and Charles Tilly while discussing the process of security in state making and relationship with its other states enjoined enforcing common laws for peaceful statism. The focus of research for state practical manifestation remained restricted to the government, bureaucracy, military and intertwined political cum societal factors thereby limiting the important factor of economic problems because of its lengthy separate subjective/objective reasons.

The state security and relationship with Indian context under the enormous revolutionary military affairs (RMA) has been researched in detail analyzing the master pieces by the scholars like Arnold Wolfer, Alastair Buchan, Richard Ullman, Lippman, Dr. Hans Gunter Brauch, Saeed Shafqat, Hassan Abbass, Hassan Askari and Rasul Bakhsh Rais. However, the traditional security concerns besides being consulted from the scholarly efforts of various scholars including David Wiscot, Spencer Tucker, Santa Barbara, B H Liddell Hart, Michael Lewis, L F Haber, Francis Fukuyama and Alex Roland, the interviews of many scholars and dignitaries have been benefitted in undertaking this research. The researcher bridging the gap of linking traditional verses non-traditional security derived all the valuable analytical arguments developing a wholesome picture of the structural faults in security dilemma between both the belligerents, India and Pakistan as an evidence of this variance.

\section{Research Question}

The research will be undertaken to unearth the question of security of a state, evolution of military and strategic security concerns and its tool, and finally the relationship and/or its practical implications over nuclear states of India and Pakistan:-

- What factors lead the nation-states to security concerns including both traditional as well as non-traditional measures in the modern age despite of interdependent economic and/or political means available particularly in the Indo-Pak scenario that already faced frequent violent and radical phases with the successful 
dismemberment with a continued deeply segmented societies making militant aggressiveness as a politically winning agenda in their statecraft?

\section{Sequence of the Research}

The study has been divided into following sub parts:-

1. Transition and evolution of traditional or non-traditional security of international/global, regional and nation state/individual levels with its effects in Indian-Pakistani context.

2. Evidence of super-imposed role of traditional military security against human security with particular reference to India and Pakistan rivalry.

3. Future prospects of traditional and non-traditional human security concerns in Indian- Pakistani scenario.

\section{Transition and Evolution}

It would be imperative that before highlighting the transition and evolution of security, the ontological and epistemological interpretations be discussed for the clarity of the concept by various scholars. Defining the word 'security', one may find out from simple definition from the Collins/World Dictionary as, 'Freedom or protection from danger/worry' ${ }^{12}$ or derivative of Merriam Webster Dictionary as, 'Freedom from fear or anxiety'. ${ }^{13}$ The Penguin Dictionary explains security as the 'Absence of threats to scarce value'. ${ }^{14}$ Empirically it is relative term in realist world as "how much security is required" referred to power attachment for removal of all threats for achievement of complete security. ${ }^{15}$

The scholars like Rousseau argue that the concept of security lays in happiness of its inhabitants and state is responsible in providing this happiness. ${ }^{16}$ Similarly, Buzan highlighted that the security as a speech act, which is a relative term, dwelling in five sectors including military, political, economics, societal and environment. ${ }^{17}$ Lippman argued that a nation may be secure if it does not sacrifice its legitimate rights against any odds. ${ }^{18}$ On the other hand, Arnold Wolfer and Alastair Buchan in their scholarly effort

\footnotetext{
${ }^{12}$ Collins/World Dictionary.

${ }^{13}$ Merriam Webster Dictionary available at www.merriamwebster.com accessed on 12 October 2016

${ }^{14}$ Graham, Evans, and Jeffrey Newham. The Penguin Dictionary of International Relations, (London: Penguin Books, 1998), pp. 343-4.

${ }^{15}$ Brauch, Dr. Hans Gunter, in eds. Brauch, Dr. Hans Gunter, P H Liotta and Antonio Marquinna, Security and Environment in the Mediterranean: Conceptualizing Security and Environment Conflicts, (Berlin: SpringerVerlag Hiedelberg, 2003), pp. 237-9.

${ }^{16}$ Carr, E H, in eds., Christopher W Hughes and Lai, Yew Meng, op.cit., pp. 106-9.

${ }^{17}$ Buzan, Barry, People, Sate and Fear: An Agenda for National Security Studies in Post-Cold war Era. (Colorado: Lynne Reiner Publishers, Inc., 1991), pp. 116-134.

${ }^{18}$ Brain, C Schmidt, in eds., Steve Smith, Amelia Hadfield and Tim Dunne, 'Foreign Policy: Theory. Actors. Cases.' (Oxford: Oxford University Press, 2008), pp. 156-7.
} 
highlighted 'Security with absence of military threat or overthrow/attack' 19 , whereas Richard Ullman opined that threat to national security may be a reaction to degrade quality of life to inhabitants, to narrow range of policies. ${ }^{20}$

In its essence, it may easily be concluded that security in its defining parameters is ambiguous which rests over psychological glass ceiling of compensation from traditional military security for survival and/or deterrence as the bottom line despite a gigantic seamless web of interdependent comprehensive security derived from economy, environment and domestic affairs of human security of the inhabitants. Moreover, the welfare states how glorious these might be in pursuance of providing its citizens', would focus over a good faith of security, freedom and liberty through legitimate monopoly of violence rested over sound police force at minimal levels. However, transition of traditional security, security and the warfare is appended in seriatim as following:-

\section{Transition of Traditional Security}

Security of Nation State or National Security started with the development of Social Contract amongst people to live in groups or modern days 'nation states' as argued by Rousseau. ${ }^{21}$ However, the scholar highlights that the transition of security started with the Individual security from 'hunting or old rivalry' for the survival against both hunger as well as the wild monsters. ${ }^{22}$ The scholarly efforts of variety of research in war against terrorism like Dwayne or Buzan however, assess that evolution of this individual security remained valid in the modern present day biometric warfare of $5^{\text {th }}$ generation where non-state actors besides a Revolution in Military Affairs (RMA) brought invisible enemies. $^{23}$

Under the aforementioned analogy, Buzan's analysis of the transformed national (state) and global security due to the modernity of military hardware from a regular army of line and column equipped with spears and swords to present days unarmed aerial vehicles i.e. drones or hidden opponent, has emerged as the latest generation of the warfare as well as security. Indeed, the traditional security of modern nation state dwelled into three dimensions of interstate wars both for ethnicity and/or religions, territorial disputes and security dilemmas leading to arms race and/or arms control. ${ }^{24}$

Modern nation states focus their security in both formerly highlighted traditional (military) and Non-traditional interdependent comprehensive security as explained by Buzan. The scholar while explaining comprehensive security divided it into four levels of individual, state, regional, and international or global securities with three tiers of

\footnotetext{
${ }^{19}$ Brauch, Dr. Hans Gunter, in eds. Brauch, Dr. Hans Gunter, P H Liotta and Antonio Marquinna, 'Security and Environment in the Mediterranean: Conceptualizing Security and Environment Conflicts', op.cit., pp. 28

${ }^{20}$ Richard, Ulman, 'Redefining Security', in International Security', Vol 8. No. 1, 1983, pp. 129-153.

${ }^{21}$ Rousseau, Jean Jacques, trans. by J D H Cole, 'On the Social Contract', (London: J M Dent, 1913), Book 1, chapter. 4 and 5.

${ }_{22}^{2}$ Ibid.

${ }^{23}$ Dwayne, N Hunt, The Invisible Enemy: The WarAgainst Terror, (Wyoming: Grace Publications, 2001), pp.68-9.

${ }^{24}$ Buzan, Barry, People, Sate and Fear: An Agenda for National Security Studies in Post-Cold war Era. op.cit., pp. 116-134.
} 
sectors, Regional Security Complex (RSC) and securitization. ${ }^{25}$ However, Machiavelli, Hobbes, Kant and Grotius duly supported by present days scholars like Morgenthau, Galton and Buzan about the conceptualization of the security of the Nation States focused over its transformation, which may be segregated into following three generations:-

a. The first generation of Security was focused traditional concept that was derived through military and generals/kings $(1600-1800 \mathrm{CE}){ }^{26}$ This phase surrounds Thomas Hobbes concept of 'Realist Security Paradigm' based over 'War of all against all'. ${ }^{27}$ The anarchic world of Hobbes Dilemma based on 'Leviathan and Orwellian State' where the feeling of 'big brother is watching you', or Machiavellian concept of 'Power centric state', required if not indefinite but colossal amount of power both in traditional as well as non-traditional security parameters. ${ }^{28} \mathrm{~A} 17^{\text {th }}$ century concept of security with a focus on realist school of thought where power was the ultimate aim however, security remained inversely proportional to individual freedom (more security for state, less individual freedom and vice versa). ${ }^{29}$ Nevertheless, this concept believed in anarchic international system and lacks institutional laws where these rules or international rules/laws are fragile to avert wars. ${ }^{30}$ Besides Thomas Hobbes, E H Carr, Morgenthau and Sigmund Freud were the scholars who professed this concept. The main pronouncement of this generation of relied over "State security through Military Power that ensured domestic peace and supreme authority to make foreign policy". ${ }^{31}$ However, the biggest critique of this concept centered in lack of rules, providing little space for consideration on institutions/organizations resolving interstate disputes.

b. Security transformed into second generation through institutions that particularly revolves from 1800 to 1950 CE, which is based over the concept of Immanuel Kant derived through Perpetual Peace ${ }^{32}$ leading to scholarly efforts of Woodrow Wilson and John Galton's 'Liberal Internationalism/Neoliberal Institutionalism' view. ${ }^{33}$ Proposal of perpetual peace 'Kantian view of moral norm to be followed by sensible man', which professes on global citizenship, an idea propagated through League of Nations ( $\mathrm{L}$ of $\mathrm{N}$ ), Concert of Europe and ultimately United Nations Organization (UNO) ${ }^{34}$ This generation of security conceptualization constituted

${ }^{25} \mathrm{Ibid}$.

${ }^{26}$ Machiavelli, Nicollo, trans. by Rufus Goodwin, 'The Prince', (Boston: Dante University Press, 2003), pp.44-7, 75-7 and 135-9.

${ }^{27}$ David, P Gauthier, Leviathan, (Oxford: Oxford University Press, 1969), pp.161-170.

${ }_{28}$ Buzan, Barry, People, Sate and Fear: An Agenda for National Security Studies in Post-Cold war Era. op.cit., pp. 1-7 and 116-134.

${ }^{29}$ Ibid.

${ }^{30}$ David, P Gauthier, op.cit., pp.161-170.

${ }^{31} \mathrm{Ibid}$.

${ }^{32}$ Kant, Immanuel, in trans., David Richardson, 'Essays and Treaties on Moral, Political and Various Philosophical Subjects', (London: Royal Exchange, 1798), pp.274-286.

${ }^{33}$ Phillip, G Cerny, Rethinking New Pluralism, (Oxford: Oxford University Press, 2010), pp. 137-167.

${ }^{34}$ Brauch, Dr. Hans Gunter, 'The Three Worldviews of Hobbes, Grotius and Kant: Foundations of Modern Thinking on Peace and Security, Contextual Change and Reconceptualisation of Security', available at www.afes-press.de/pdf/Hague/Brauch_worldview.pdf, accessed on 10 October 2016, pp. 237-9. 
over 'Republican constitution and federal state system', ${ }^{35}$ which was bound by rules of international law/institution(s) to avert any future conflict thereby threatening the security of the particular state. ${ }^{36}$ Formulation of concert of Europe, League of Nation and UNO were the optimistic approaches thereby terming the proponents of this ideology as the 'Revolutionists and Universalists'. ${ }^{37}$ Moreover, the focus of this ideology rested over supra-natural authority of the aforementioned organizations for implementation of peace through institutions/international law with the basic conceptualization of an idea of "Pen is mightier than sword". 38 The biggest critique of the concept rested on the lack of power to exercise the legitimate monopoly of coordination both at global and international levels that was evidently proved in fragile construction of the highlighted organizations in averting World War (WW) I and WW II.

c. The third generation of Security emerged through associating traditional military phenomenology with non-traditional military security by its ingredients including politics, economy, environment and society holding its roots with human security in domestic affairs during the last period of the Cold War or more precisely beyond 1960 till to date bounded by rules and institutions jointly. ${ }^{39}$ Hugo Grotius initially and later Barry Buzan, Ole Weaver and Jaap De Wilde conceptualized security bounded by rules and institutions to deal with the states with police authority for implementation of peace in the world combining Neorealist's/Neoliberal's ideology with a blend of Neo-Weberian monopoly of legitimate coordination as well as violence. This generation of security may in the simplest form be elaborated as a mixture of above mentioned two generation security concepts which had both the ingredients of police rule/authority with peace that is to say an Institutional approach with power per se. The ideology had a concept of using force with a respect for human beings or a collective security through organizations like $\mathrm{L}$ of $\mathrm{N}$ /UNO. ${ }^{40}$ However, the biggest critique over the role of institutions as was the case in first generation of security concepts was pronouncedly observed evidently observed with limited and biased abilities of UNO with special reference to having a treasury book with USA.

The critical analysis of aforementioned generations of security paradigm is quite obviously debatable as for as its intermediately time period is concerned because the sequential arrangement may develop second and third generations as interchangeable between Kantian and Grotius security concepts due to the scholars' life duration. In its essence, the rearrangement may not be valid due to the international human rights law or

\footnotetext{
${ }^{35}$ Kant, Immanuel, in trans., David Richardson, 'Essays and Treaties on Moral, Political and Various Philosophical Subjects', op.cit., pp.274-286.

${ }^{36} \mathrm{Ibid}$.

${ }^{37}$ Brauch, Dr. Hans Gunter, 'The Three Worldviews of Hobbes, Grotius and Kant: Foundations of Modern Thinking on Peace and Security, Contextual Change and Reconceptualisation of Security', available at www.afes-press.de/pdf/Hague/Brauch_worldview.pdf, accessed on 10 October 2016, pp. 7-8.

${ }^{38}$ Buzan, Barry, People, Sate and Fear: An Agenda for National Security Studies in Post-Cold war Era. op.cit., pp. 116-134.

${ }^{39}$ Brauch, Dr. Hans Gunter, in eds. Brauch, Dr. Hans Gunter, P H Liotta and Antonio Marquinna, Security and Environment in the Mediterranean: Conceptualizing Security and Environment Conflicts, op.cit., pp. 237-267.

${ }^{40}$ Ibid.
} 
international law ideology of Grotius was carried forward by the scholars of this century which nevertheless made it the refined form of previously conceptualization security generation. Moreover, the concept of Perpetual Peace or Eternal Peace argued by Kant had a definite set back due to the failure of $\mathrm{L}$ of $\mathrm{N}$ and initiation of WW II or former WW I.

In a nutshell, security of a state was focused during first generation on three-fold reasons that is first, against interstate wars, may these be ethnic or religious, second against territorial disputes and finally in pursuit of security dilemma that forces the nation states in arms race or arms control regimes. ${ }^{41}$ In the second phase the reasons were almost the same to be eradicated through institutions but in third generation the aforementioned 'casus belli' of 'just security' was bounded in 'war with good faith' ${ }^{42}$ dwelling in laws because of the reasons; first, defense or protection of the state, second in recovery of the property and finally in award of punishment. ${ }^{43}$

\section{Five Generations of Warfare}

It would be indeed pertinent to first find out a transition of the warfare to bridge a gap between traditional security and the war generations which worked in hand and glove in modernity to augment each other until to date. Inventions of modern weaponry and war munitions were introduced in scattered areas and era but the restriction of evolution of under mentioned generations of warfare are derived with the evolution of modern nation states' concept that probably marked the beginning of both the evolving features otherwise the classic military master pieces both in execution and evolution existed in history elsewhere also. The evolution of warfare argued by many scholars and war analysts including David Wiscot, Spencer Tucker, Santa Barbara, B H Liddell Hart, Michael Lewis, L F Haber, Francis Fukuyama and Alex Roland revolve around five or four generations of warfare however, it is indeed the researchers division based over the scholarly efforts of aforementioned analytical reviews, which are seriatim highlighted and appended below:-

1. $1^{\text {st }}$ Generation- Pre-Napoleonic. This generation starts with the regular armies that fought organizing over the technique of 'Line and Column Technique of fighting in the battle field' whereas the technological advancement started from a 'Smooth Bore Rifles' of 1500 to 1700 CE era.

2. $2^{\text {nd }}$ Generation- Pre-Napoleonic. It is basically an organized warfare that involved 'Trench Warfare' to fight an offensive or defensive battle in a dug out called a trench. The technological advancement of this generation marks a beginning of 'Rifled Bore' weapons of 1700 to $1800 \mathrm{CE}$ or early phase of a gun that had a piercing shot.

\footnotetext{
${ }^{41}$ Buzan, Barry, People, Sate and Fear: An Agenda for National Security Studies in Post-Cold war Era. op.cit., pp. 116-134.

${ }^{42}$ Brauch, Dr. Hans Gunter, 'The Three Worldviews of Hobbes, Grotius and Kant: Foundations of Modern

Thinking on Peace and Security, Contextual Change and Reconceptualisation of Security', available at www.afes-press.de/pdf/Hague/Brauch_worldview.pdf, accessed on 10 October 2016, p. 6.

${ }^{43} \mathrm{Ibid}$.
} 
3. $3^{\text {rd }}$ Generation- Napoleonic Warfare marks with the invention of Machine Gun, Breech Loading Rifles and guns of 1800 to $1930 \mathrm{CE}$.

4. $4^{\mathrm{TH}}$ Generation warfare. This generation is basically marks the period of technological revolution which started the warfare on flying machines i.e. the 'Modern Warfare of Aircrafts', invention of huge dread knots and nuclear arsenals of 1930 to $1988 \mathrm{CE}$. However, the delivery of nuclear weapons was restricted to the conventional aircrafts.

5. $5^{\mathrm{TH}}$ Generation of warfare. Besides a revolution in military affairs (RMA), this generation is focused over the involvement of 'Non-State Actors' and unarmed aerial vehicles (UAVs) or drones/biometric bullets, standoff warfare which started after 1990 till to date. This generation of warfare basically had an invisible enemy that may be sitting outside the sphere of war zone operating its tentacles.

\section{Traditional or Military Security}

The research in decline of traditional military security focused over strong military force or arsenals in comparison to human or other interdependent security sectors in international politics remained a prime probing question. However, the over increasing spending of major portion of the budget itself is an indicator of aforementioned argument. The details of the average budget expenditures of top nine nation state including India and Pakistan are attached at annexure A. Moreover, the traditional military security that is state centric security defining issues related to state survival besides the use of force or violence for security of any state involves or measured in military terms. ${ }^{44}$

In its essence, traditional military security being unending urge due to its always insufficient to the ambiguous threats remained confined to the development of twofold conceptual debates including first that the military threats are less prevalent hence require less attention to the military security, while others feel military force is useful tool of state craft and state require to dwell more in establishing its military force in worthwhile terms. ${ }^{45}$ The former proponents' category of scholars professes to reexamine the national security and IR, especially after the post cold war period.

The concept of the reduction in military security believes in broadening the view of national security which has two dimensions first, to include domestic problems in security of a nation state and second, to include non military or external threats to national security. ${ }^{46}$ Contrarily, the opponents of above mentioned category i.e. the military security believers argue that the $5^{\text {th }}$ generation of warfare developed a new 'secret war or the war of hatred' because of non-state actors and the revolution in

${ }^{44}$ Dwayne, N Hunt, the Invisible Enemy: The War Against Terror, op.cit., pp.13-9 and 68-9.

${ }^{45}$ Phillip, G Cerny, Rethinking New Pluralism, op.cit., pp. 137-167, and David, P Gauthier, op.cit., pp.161170.

${ }^{46}$ Brauch, Dr. Hans Gunter, 'The Three Worldviews of Hobbes, Grotius and Kant: Foundations of Modern Thinking on Peace and Security, Contextual Change and Reconceptualisation of Security', available at www.afes-press.de/pdf/Hague/Brauch_worldview.pdf, accessed on 10 October 2016, pp. 7-9. 
military affairs (RMA) brought a more sophisticated invasion of invisible enemy necessitate for ever increasing physical and moral efforts. ${ }^{47}$

\section{Evolution of traditional military security with its impacts on Indo-Pak rivalry}

Generally it is a misleading impression of evolution of traditional military security that started after the conduct of two nuclear attacks by USA over Japan in WW II. ${ }^{48}$ Despite the ambiguity of security and overarching requirement of unending traditional military security the states remained focused over traditional security because of four basic reasons including first, the requirement of military power in prevention of war. Second, to fight a war in good faith bounded by laws for defense require building traditional might. Third, recovery of property and finally punishing the defaulters required a definite power centric preparation. ${ }^{49}$ However, the evolution of traditional security may be focused over four distinct phases as appended below ${ }^{50}$ :-

a. Survival. Indeed this phase of the traditional security started since ages from the 'individual security' of old ages man of hunting requiring specific weapons as well as ground for hunting and safety against wild life. However, the modern development of traditional security starts with Machiavelli, Foch, Bloch and Clausewitz. It is not intended to bifurcate both, 'English or Copenhagen School' of thought from 'American school' of traditional security but indeed two major schools of John Hopkins and Colombia University in later, whereas Woodrow Wilson and John Galton in the former category developed new concepts for the military security studies.

In its essence, the major diversification in traditional security studies started with Quincy Wright and Clausewitz's conceptualization of war as instrument of statecraft or otherwise where the former in 1942 developed 'study of war' and highlighted war as problem to be solved/cured rather than an instrument of state craft. $^{51}$ On the contrary, reliance on Clausewitzian concept of security that is military power is the policy of national security being the prima fascia of the statecraft amongst nation states as argued by Clausewitz and Morgenthau and the scholars of this ideology. Indeed, it was until mid 1950s that the phase of survival of nation states focused traditional military security as center of attention of national security more a premise than the topic of debate and central instrument of statecraft. $^{52}$

b. Deterrence. Traditional military security concerns after the WW II were transforming its façade to shifting of national security from the means of security that is military state craft to goals of security that is political state craft. ${ }^{53}$ However,

\footnotetext{
${ }^{47}$ Alexander, John B, Future War: Non-lethal Weapons in Modern Warfare, (St. Martins: St. Martins Press, 2010), pp. 33-9, 43-7 and 123-9.

${ }^{48}$ David, A Baldwin, 'The Concept of Security', in The Review of International Studies, vol. 1997., pp. 8-11.

${ }^{49}$ Ibid.

${ }^{50}$ Ibid.

${ }^{51}$ Ibid.

${ }^{52}$ Ibid.

${ }^{53}$ Graham, Evans, and Jeffrey Newham. The Penguin Dictionary of International Relations, op.cit., pp. 126-7.
} 
after 1940's, instead of a concern due to massive death toll and destruction to the property, it was military security force predominantly became as cause instead a source of security of nations. Indeed, 1950 post WW II developments posed serious concerns for traditional military security due to mass retaliation against nuclear weapons or against the military power itself but the continued attainment brought the world as a nuclear flash point between two super powers. ${ }^{54}$ Henceforth relevance of traditional security and its epistemological understanding was termed as the 'golden age' from 1955 to 1965 under the 'Development of deterrence theory' by American school of thought ${ }^{55}$ where the focus on threat manipulation and forced projection remained as central idea in the traditional military security. Similarly, besides the golden era of traditional security a matching revolution in the warfare was also evaluating to its final generation thereby bringing new concepts of warfare with compatible technology. ${ }^{56}$

In its essence, however after 1960s traditional military security was taking lower shade to economic/welfare security besides national security was accompanied by both traditional military and non-traditional military/techniques of statecraft i.e. focus over human security or domestic affairs with an awareness of security of state dilemma.

c. Détente. The transformation of third phase of traditional military security dwelled in its ongoing decline due to threefold reasons of its massive failures as argued by Graham and Jeffery, first, the massive retaliation in domestic domains inside USA and USSR for wars in Vietnam and Afghanistan in 19651966 and 1979-87 respectively where the later was disintegrated after couple of years for other obvious reasons also. ${ }^{57}$ Baldwin similarly argues that the détente phase of 1980's cold war and transformation of national security to international security became post cold war order of the day. ${ }^{58}$ It was indeed due to the strong public opinion and human security that relegated the high sounding focus of traditional security to next final phase as well as a major cause of former USSR's disintegration due to the fragile internal state structures, global capitalist institutions and democratic ideology transforming Weberian concept of legitimate monopoly of violence to monopoly of coordination as highlighted by Baldwin. ${ }^{59}$

d. Interdependent Comprehensive Security. Reliance over traditional military security after the collapse of former USSR and uni-polar world after 1990s post cold war saw a transformed traditional security from national security to international or global security bringing other sectors into its domain as argued by Buzan. $^{60}$ A set of scholarly thought process of security standards originated by Barry Buzan, Ole Weaver and Jaap De Wilde focused on three basic key concepts

${ }^{54}$ Ibid.

${ }^{55}$ David, A Baldwin, 'The Concept of Security', in The Review of International Studies, vol. 1997., pp. 8-11.

${ }^{56}$ Graham, Evans, and Jeffrey Newham. The Penguin Dictionary of International Relations, op.cit., pp. 126-7.

${ }^{57} \mathrm{Ibid}$.

${ }^{58}$ David, A Baldwin, 'The Concept of Security', in The Review of International Studies, vol. 1997., pp. 8-11.

${ }^{59} \mathrm{Ibid}$.

${ }^{60}$ Buzan, Barry, People, Sate and Fear: An Agenda for National Security Studies in Post-Cold war Era. op.cit., pp. 116-134. 
of sectors, Regional Security Complex (RSC) and Securitization (Bill Mcsweeney coined the term, Comprehensive Security), where sectors highlighted traditional Military security to five sectors' security, also termed as comprehensive security, comprised of Military, Political, Economics, Societal and Environment. ${ }^{61}$ Each sector widened the security parameters to new dimensions. Second, RSC explained the interdependence of security on regions, because most threats travel at short distances. Third, Securitization is a process, as argued by Buzan where certain issue is transformed (by an actor) as matter of security. It aims at who securitizes (securitizing actors) on what issue (threats) for whom (referent objects), why, with what rules and under what conditions i.e. why securitization with what agent/actor, referent object and audience by what reasons. ${ }^{62}$ The example quoted by the scholar highlighted the case study of American invasion of Iraq in 2003 where 'USA was actor while WMD was object and world, USA, Iraq were the audience respectively'.

Buzan argued that the traditional security in post cold war scenario because of Perestroika, Glasnost and fluidity or openness of core and centre state capitalism as well as mercantilism after 1989, have changed relationship between great powers of the North (or centre/core) for states in south (or periphery) due to post east/west powers relations, traces and consequences. ${ }^{63}$ Western capitalism has triumphed over both communism and third world ideology besides raising and subsequently negating the bipolar theory of balanced powers to unipolar world that is emerged undecided power balance where bottom line of security being survival remained concern of periphery. Periphery and core rivalry widened to the extent that state would desire to be lowest members of the core/centre rather than to be highest of periphery. The traditional security encompassed five major components as argued by Buzan to formulate an interdependent concept of comprehensive security. ${ }^{64}$

These included first, the traditional military security. Major component of security lays, as argued by Buzan, in which state or government is responsible with basic duty to protect citizens and protect layers of individual and social interests dwell in traditional military security. However, the scholar asserts that the military security concerns the two levels inter play of armed offensive and defensive capability of states against the states perception of each other intentions which should cater in real calculations despite unending perceptions bounded with the mis-calculative security threats. ${ }^{65}$

Second, Buzan highlighted that political security and stability of political organizations is the prime requirement, which may affect other states unstable due to the 'Domino effect'. Diversified interest of political state may not pose security concerns if all pillars Government, Territory, State and Sovereignty, are intact. ${ }^{66}$

${ }^{65}$ Ibid.

${ }^{66} \mathrm{Ibid}$. 
Political security concerns the organizational stability of states and system of government. Third, economic security has direct effect on military and political security. Budget constraints started posing serious threats that has direct effect on causes of war (Military Keynesianism). ${ }^{67}$ Economic security concerns access to the resources, finance and markets necessary to sustain acceptable levels of welfare and state power.

The fourth interdependence sector of the security was based on societal security that encompassed collective identity of "we" which may be ethno or religious. It may be converted into permanent through three ways of migration, horizontal and vertical competitions. ${ }^{68}$ Societal Security concerns the ability of societies to reproduce their traditional patterns of language, culture, association of religion, national identity and customs within acceptable condition of evolution.

Finally the last component of comprehensive security revolves around 'Environment' where the concerns of maintenance of the local and planetary biosphere as essential support system on which all other human enterprise depend including water wars, pollution, global warming and green peace that can be addressed at domestic, bilateral, regional and global levels. ${ }^{69}$ The biggest argument of the scholar focus a requisite availability of clean air to breath and having a sip of clean drinking water is necessary or the gun to use in warfare, being a worth probing reality.

\section{Evidence of Traditional Military Security between India and Pakistan}

Traditional security between the belligerents remained confined to aforementioned first two phases with a limited time lag of next two phases for shortest possible durations that too with a limited sphere and/or share both in budget as well as foreign policy transforming the traditional societies of both the states growing public opinion in typical orthodox normative post-colonial masses. ${ }^{70}$ Development of law of diminishing marginal utility world over was progressing reliance on reduction on military security post cold war ideology due to disintegration of former USSR, focus on economic, human/societal and environment securities. ${ }^{71}$ On the contrarily, world was also evaluating to globalized interdependent security complex developing national security hinged over the former because security could not be insured completely spending total assets over traditional military arsenals. Second, the minimal not even mezzo level

\footnotetext{
${ }^{67}$ The concept of military Keynesianism was duly highlighted by John Maynard Keynes (188- 1946), who was an economist in Cambridge, England. The scholar provided 'Keynesian Theory' in 1930 during 'Great Depression' of economy to avert the crisis of military spending.

${ }^{68}$ Buzan, Barry, People, Sate and Fear: An Agenda for National Security Studies in Post-Cold war Era. op.cit., pp. 116-134.

${ }^{69}$ Ibid.

${ }^{70}$ David, A Baldwin, 'The Concept of Security', in The Review of International Studies, vol. 1997., pp. 8-11.

${ }^{71}$ Brauch, Dr. Hans Gunter, 'The Three Worldviews of Hobbes, Grotius and Kant: Foundations of Modern

Thinking on Peace and Security, Contextual Change and Reconceptualisation of Security', available at www.afes-press.de/pdf/Hague/Brauch_worldview.pdf, accessed on 10 October 2016, pp. 7-9.
} 
security would suffice survival/ sustenance of states besides being its ambiguity as well as after the collapse of former USSR and failure of America in Vietnam. ${ }^{72}$

Pakistan as well as India instead of concentrating over bread, butter, clean air/ water for human development continuingly went for stock piling of military security which made the internal structure more prone to violence and radicalization. Rational policy making with equally diverting funds to all other sectors remained questionable amongst governments of both the states, which made military security always being in conflict with other goals/securities that instead of marginal utilities of expenditure on bread subservient to exceedingly fragile to marginal utilities of expenditure on guns. ${ }^{73}$ Evidence prove that the more aggressive prone governments in India as well as Pakistan brought disastrous conditions for the society in importing enormous marginal welfare besides putting division of its one half in the later case.

The international world states presently are planning policies to spend more on public policy than on military security or as argued by Hans, shifting to un-Clausewitzian dictum 'traditional military is merely the instrument of state policy'. ${ }^{74}$ It was rather a paradigm shift of traditional military security and state craft moving understandably in cold war era is not justifiable but now it was questionable. Contrarily, the belligerents were fragile to switching generation of domestic affairs in non-traditional security indeed for bilateral reasons of political elite designed at enhanced conservative public opinion of animosity oriented at each other duly supported by the state elements and second the traditional society least concerned over domestic security concerns of crisis on education, exploding population growth with increasingly under class/poverty, and underinvestment in production capacity/structure. ${ }^{75}$

In a nutshell, the focus of both India and Pakistan remained confined to the traditional military security predominantly due to the both internal as well as external reasons despite a changing global world towards a clash with realists specially after incorporating domestic affairs mainly against paradigm of anarchic state centrism. Moreover, fragile equipped traditional security with reference to RMA and its huge expenditures versus public good, economic, environment, and foreign policy/political security were least considered worthwhile by the traditional societies of both the states equally unimportant. ${ }^{76}$ It may easily be concluded from the above discussion that both the belligerents were focused over huge expanditures from their meager resources on traditional security instead of interdependent non-traditional means of security thereby concentrating over the welfare of the society.

\footnotetext{
${ }_{72}^{72}$ David, A Baldwin, 'The Concept of Security', in The Review of International Studies, vol. 1997., pp. 8-11. ${ }^{73} \mathrm{Ibid}$.

${ }^{74}$ Brauch, Dr. Hans Gunter, 'The Three Worldviews of Hobbes, Grotius and Kant: Foundations of Modern Thinking on Peace and Security, Contextual Change and Reconceptualisation of Security', available at www.afes-press.de/pdf/Hague/Brauch_worldview.pdf, accessed on 10 October 2016, pp. 7-9.

${ }^{75}$ David, A Baldwin, 'The Concept of Security', in The Review of International Studies, vol. 1997., pp. 8-11.

${ }^{76}$ Brauch, Dr. Hans Gunter, 'The Three Worldviews of Hobbes, Grotius and Kant: Foundations of Modern Thinking on Peace and Security, Contextual Change and Reconceptualisation of Security', available at www.afes-press.de/pdf/Hague/Brauch_worldview.pdf, accessed on 10 October 2016, pp. 7-9.
} 


\section{Effects and Future prospects of traditional military and non-military security between the belligerents}

Pakistan and India indulged in a series of small scale and full-fledged wars since their inception despite clarity of calculating a definite clarification at both states' level because the resultant remained mostly a zero sum game, ${ }^{77}$ particularly after the attainment of nuclear status. Indeed, both the states have enhanced threat and traditional military security concerns ever increasingly enormous. The conceptualization of prisoner's and security dilemma has not let reduce the decisions of rational choices to irrational outcomes therefore both the states never let the traditional security at any change since last decades. ${ }^{78}$ Resultantly, both the belligerents are in arms race and stockpiling of military arsenals instead of human security hence lacking welfare of state and society.

The prospects of easing to détente or interdependent comprehensive security phase may work efficiently provided modest reforms by both the states duly supported by the society would focus over non-traditional security including environment, economic, societal, political and regional aspects of security without compromising the ever demanding so called military security. ${ }^{79}$ Contrarily, the ongoing invention of $5^{\text {th }}$ generation warfare of secret or hatred war duly intensified due to RMA would require a radical change to eliminate violations of human rights, protection for environment, fight against epidemics, crime, and social injustice in both the belligerent states thereby relegating traditional military security to lower levels despite an urge from both elite of the states' and/or traditional society(s). ${ }^{80}$

In its essence, phenomenological uprising of the security dilemma ${ }^{81}$ that forces both the states to feel threatened and take military developmental measure in response to the security measure of the other state require each state to détente over stock-piling of the military hardware. Moreover, military Keynesianism which brought economy of both the states subservient to the defense building to export level hopes and expenditures at the cost of developments needs to be reframed and exchequer be diverted to human security and human development projects as highlighted above. Evidently, the outcome encircled the enormous reliance over traditional security transforming the state as well as society slave of realist paradigm focused over 'ready to war' status directing maximum of its resources unilaterally in security dilemma of might against the other.

\section{Conclusion}

Traditional military security has forced the world in general and South Asian region particularly over stockpiling of military hardware including the nuclear arsenals focused, on the conceptualization of India-Pakistan security dilemma, making it a flash point. The belligerents involved into vicious circle of traditional military security

\footnotetext{
${ }^{77}$ Ibid.

${ }^{78}$ Buzan, Barry, People, Sate and Fear: An Agenda for National Security Studies in Post-Cold war Era. op.cit., pp.116-134.

${ }_{79}$ Ibid.

${ }^{80} \mathrm{Ibid}$.

${ }^{81}$ Ibid.
} 
arsenals based over traditional enthusiasm of ethnic and religious vehemence of the traditional society which was relegated to massive poverty, illiteracy and bottom line of the human security. The Indian as well as Pakistani elite instead of finding out the prospects of taking human security measures besides an effort to détente and interdependent comprehensive security precisely transforming both the states into welfare states remained concentrated on the personal ulterior motives using the trump card of the traditional military hardware stockpile. Following the European Union's regional cooperation model of integration for prosperity of the region, contrarily both the states particularly diminished the welfare states' concepts duly supported by the traditional society in pursuit of their secondary goals to maintain traditional military hardware with vigorous speed.

In its essence, India and Pakistan had to revert back to find out the prospects of human security, freedom and liberty besides a massive efforts in elevating poverty, literacy and human security through more reliance on non-traditional welfare steps shedding away the existing devolution of traditional hype and display of traditional military might. It is indeed high time that the leadership as well as the societies of the belligerents' take concrete steps in making their state a real 'welfare state' for secure human life and property through cooperation and interdependent security relegating the traditional security to its lower tiers thereby extracting more from the already meager resources. 
Annexure A

Spending over Traditional Military Security ${ }^{82}$

\begin{tabular}{|l|l|l|l|l|l|l|}
\hline Ser & Country & $\begin{array}{l}\text { Spending } \\
\text { in billion } \\
\$\end{array}$ & $\begin{array}{l}\text { Percentage } \\
\text { of GDP }\end{array}$ & $\begin{array}{l}\text { World } \\
\text { Share } \\
\text { Percentage }\end{array}$ & $\begin{array}{l}\text { Budget } \\
\text { income }\end{array}$ & $\begin{array}{l}\text { Budget } \\
\text { expenditure }\end{array}$ \\
\hline 1 & USA & 650 & 4.7 & 41 & 23030 & 35990 \\
\hline 2 & China & 150 & 2.0 & 8.2 & 16460 & 17290 \\
\hline 3 & Russia & 81 & 2.9 & 4.1 & 3828 & 3762 \\
\hline 4 & UK & 63 & 2.6 & 3.6 & 9860 & 11880 \\
\hline 5 & France & 63 & 2.3 & 3.6 & 13860 & 15350 \\
\hline 6 & Japan & 60 & 1.0 & 3.4 & 19710 & 24950 \\
\hline 7 & KSA & 50 & 8.7 & 2.8 & 1870 & 1840 \\
\hline 8 & India & 48 & 2.5 & 2.7 & 1854 & 2698 \\
\hline 9 & Germany & 47 & 1.3 & 2.7 & 15570 & 15880 \\
\hline 33 & Pakistan & 5.16 & 0.9 & 0.7 & 22.14 & 32.09 \\
\hline
\end{tabular}

82 www.http//:ourworldindata.org/military-spendings/ and http//:cow.dss.ucdavis.edu/data-sets/nationalmaterials-capabilities both accessed on 12-14 August 2016. The spending and relevant date is an average of last three years that is from 2013 to 2015 available, which is rounded off to nearest hundred/tens. 
Annexure B

Factors Effecting the Security Concerns of the States at all Levels ${ }^{83}$

\begin{tabular}{|c|c|c|c|}
\hline & Macro factors & Mezo factors & Micro factors \\
\hline $\begin{array}{l}\text { Crucial } \\
\text { actor }\end{array}$ & $\begin{array}{l}\text { Potential Threats, } \\
\text { International or } \\
\text { Global } \\
\text { World }\end{array}$ & $\begin{array}{l}\text { Regional and sub } \\
\text { regional associations }\end{array}$ & $\begin{array}{l}\text { Individual persons, } \\
\text { societies and states }\end{array}$ \\
\hline $\begin{array}{l}\text { Crucial } \\
\text { factors }\end{array}$ & $\begin{array}{l}{ } \begin{array}{l}\text { Stability of the } \\
\text { world peace }\end{array} \\
>\text { Role of } \\
\text { international } \\
\text { organizations in } \\
\text { foreign } \\
\text { interventions } \\
>\text { Nuclear } \\
\text { proliferation } \\
>\text { Environmental } \\
\text { depletion } \\
>\text { Human rights } \\
\text { violations } \\
>\text { Conflicts, } \\
\text { violence and } \\
\text { repression }\end{array}$ & $\begin{array}{l}\Delta \quad \begin{array}{l}\text { Stability of } \\
\text { regional security }\end{array} \\
>\quad \begin{array}{l}\text { Nuclear and war } \\
\text { munitions } \\
\text { discipline }\end{array} \\
>\quad \begin{array}{l}\text { Stabile } \\
\text { environmental } \\
\text { and regional } \\
\text { warming factors }\end{array} \\
>\quad \begin{array}{l}\text { Technology } \\
\text { diffusion }\end{array} \\
>\begin{array}{l}\text { Flexibility of } \\
\text { policies on } \\
\text { regional human } \\
\text { rights violations }\end{array} \\
>\begin{array}{l}\text { Stoppage of } \\
\text { escalation in } \\
\text { conflicts due to } \\
\text { domino effects }\end{array} \\
>\begin{array}{l}\text { Ethno- religious } \\
\text { dilemmas }\end{array}\end{array}$ & $\begin{array}{ll} & \begin{array}{l}\text { Stability of state } \\
\text { security }\end{array} \\
> & \text { Human security } \\
> & \begin{array}{l}\text { Poverty elevation } \\
\text { and food, water, } \\
\text { shelter stability }\end{array} \\
> & \text { Disease security } \\
> & \text { Trust in institutions } \\
> & \begin{array}{l}\text { Minimizing social } \\
\text { exclusion } \\
\text { (maximize } \\
\text { individual } \\
\text { reputation), }\end{array} \\
> & \begin{array}{l}\text { Education } \\
>\end{array} \\
\begin{array}{l}\text { Minimizing phobias } \\
\text { and various -isms }\end{array} \\
>\begin{array}{l}\text { Degetoising, free } \\
\text { movement of } \\
\text { individuals }\end{array}\end{array}$ \\
\hline
\end{tabular}

${ }^{83}$ Data tabulated from the concluding analysis and the succeeding scholarly efforts in the context of Pakistan and Indian security dilemma particularly highlighted by Buzan in his scholarly effort in, 'People, Sate and Fear: An Agenda for National Security Studies in Post-Cold war Era'. 


\section{Bibliography}

\section{Books}

Alexander, John B, Future War: Non-lethal Weapons in Modern Warfare, St. Martins: St. Martins Press, 2010.

Brain, C Schmidt, in eds., Steve Smith, Amelia Hadfield and Tim Dunne, 'Foreign Policy: Theory. Actors. Cases.' Oxford: Oxford University Press, 2008.

Brauch, Dr. Hans Gunter, in eds. Brauch, Dr. Hans Gunter, P H Liotta and Antonio Marquinna, Security and Environment in the Mediterranean: Conceptualizing Security and Environment Conflicts, Berlin: Springer-Verlag Hiedelberg, 2003.

Buzan, Barry, People, Sate and Fear: An Agenda for National Security Studies in PostCold war Era. Colorado: Lynne Reiner Publishers, Inc., 1991.

Caroline, Kennedy in eds. Collins, Alans, Contemporary Security Studies, Oxford: Oxford University Press, 1983.

Carr, E H, in eds., Christopher W Hughes and Lai, Yew Meng, Security Studies: A Reader, Oxon: Routledge, 2011.

Collins/World Dictionary.

David, A Baldwin, 'The Concept of Security', in The Review of International Studies, vol. 1997.

David, P Gauthier, Leviathan, Oxford: Oxford University Press, 1969.

Dwayne, N Hunt, The Invisible Enemy: The WarAgainst Terror, Wyoming: Grace Publications, 2001.

Fanny, Coulomb, in eds., Derek, L Braddon and Keith Hartley, Handbook on the Economics of the Conflict, Glos, UK: Edward Elgar Publishing Limited.

Graham, Evans, and Jeffrey Newham. The Penguin Dictionary of International Relations, London: Penguin Books, 1998.

Kant, Immanuel, in trans., David Richardson, 'Essays and Treaties on Moral, Political and Various Philosophical Subjects’, London: Royal Exchange, 1798.

Machiavelli, Nicollo, trans. by Rufus Goodwin, 'The Prince', Boston: Dante University Press, 2003.

Merriam Webster Dictionary available at www.merriamwebster.com accessed on 12 October 2016.

Phillip, G Cerny, Rethinking New Pluralism, Oxford: Oxford University Press, 2010. 
Richard, Ulman, 'Redefining Security', in International Security', Vol 8. No. 1, 1983.

Rousseau, Jean Jacques, trans. by J D H Cole, 'On the Social Contract', London: J M Dent, 1913, Book 1, chapter. 4 and 5.

Russel, F Leng, in eds., T V Paul, The India-Pakistan Conflict: An Enduring Rivalry, Cambridge: Cambridge University Press, 2005.

\section{Periodicals/Journals}

Brain, M Drinkwine, Colonel, The Serpent in our Garden: Al Qaida and the Long War, available on http://www.strategicstudiesinstitute.army.mil/. Accessed on 12 October 2016.

Brauch, Dr. Hans Gunter, 'The Three Worldviews of Hobbes, Grotius and Kant: Foundations of Modern Thinking on Peace and Security, Contextual Change and Reconceptualisation of Security', available at www.afes-

press.de/pdf/Hague/Brauch_worldview.pdf, accessed on 10 October 2016. 